\title{
Concept and Implications of Service in Christianity from the Perspective of Mary Bethany and Judas Iscariot's Activities with Jesus
}

\author{
M. M. Oboh, $\mathrm{PhD}^{1 *}$, B. I. Oboh ${ }^{2}$ \\ ${ }^{\mathrm{T}}$ Baptist College of Theology, P. O. Box 2380, Benin City, Edo State, Nigeria \\ ${ }^{2}$ College of Education, Ekiadolor now Tayo Akpata University of Education, Benin City, Edo State, Nigeria
}

\section{Article History}

Received: 26.07.2020

Accepted:13.08.2020

Published: 30.10 .2020

Journal homepage:

https://www.easpublisher.com/easjhcs

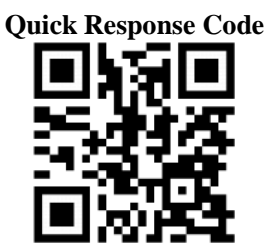

Abstract: This paper underscores the fact that service in whatever level or area particularly in Christianity has some very serious implications. It either leads to commendation or condemnation of the one who renders it. However, the result of whether it is of reward or repercussion depends on an individual's deeds in compliance or rejection of Christian norms and values such as love, faithfulness, righteousness, justice, obedience, holiness and so on. It is demonstrated in Mary Bethany (Mary of Bethany) and Judas Iscariot's interactions with Jesus (Mt. 26:6-13, 14-16, 20-25, 47-50; Mk. 14:3-9,10-11, 17-21, 43-46; Lk.10:38-42; 7:36-50; Jn. 12:1-8; 11:1-2,28-30). While Mary stands out as an example of one who deserves to be commended, Judas fits in as one condemned. Thus, the paper examines their historical background, encounter, services and their corresponding relationship to Jesus as well as the society. In the same vein, it draws on their implications and applies same to caution, enlighten, teach and enjoin Christians on the need to render justifiable services to God and humanity in order to avail themselves of its benefits rather than of disservice and condemnation.

Keywords: The paper contains some key elements or words that are vital for its understanding. These are service, Christianity, Christian, love, faithfulness, righteousness and holiness.

Copyright (C) 2020 The Author(s): This is an open-access article distributed under the terms of the Creative Commons Attribution 4.0 International License (CC BY-NC 4.0) which permits unrestricted use, distribution, and reproduction in any medium for non-commercial use provided the original author and source are credited.

\section{INTRODUCTION}

Service is the work performed by an individual in God's honour and directed toward meeting human needs. It is approached in a selfless manner and does not consider personal interest above those of others (Mk. 12:30-31). This opinion agrees with C. G. Kruse's (1993:137) description of service as the duty rendered by "Paul, his colleagues and believers generally and also of those appointed to fulfill special functions within the Christian communities..." Christianity is the practice of a belief system centred on the salvific work of Christ. It is tailored towards the service and worship of God as embedded in the expression of love and care to people. Reward is attached to it and looks forward to a final consummation in heaven at the end of the age (Jn. 3:16-18, 14:1-4; Matt. 28:18-20). Christianity is simply defined by D. F. Wright (1988:155) as the faith that "confesses Jesus Christ to be the sole mediator between God and mankind (1 Tim. 25, cf. Jn. 14:6; Acts 4:12)."

Christian is the name of a person who subscribes to the practice of Christianity by believing in the person of Christ and promising to imbibe with His teachings. Being a Christian has spiritual implications. It is experienced by those who genuinely confessed Him. Therefore, Christianity has a deeper understanding beyond a name and mere church attendance or involvement in Christian activities (Mt. 13:1;Lk. 12:12; Jn. 14:26, 20:22; Ac. 11:26).

The term Christian is used in three different places of the New Testament, Acts 11:26, 26:28 and in 1 Peter 4:16. Its first usage in Antioch (Ac. 11:26) occurred in the early forties. Persecutors of believers in the city had used it to qualify them based on their understanding of the teachings of Paul and Barnabas about Jesus Christ whom they (the persecutors or mob) believed to be the founder of the new religion. From then onward, it gained the usage of both believers and those who did not as visible from the reference to the New Testament. Nevertheless, its knowledge was not as widely known compared to what the Christians had used for themselves which were ' '...disciples,' 'brethren,' 'saints,' 'righteous,' 'poor,' 'believers,' 'those being saved,' 'elect,' 'those of the way' etc (O. A. Piper, 1963:139).

Thus, Christianity was initially specifically in the early or ancient church regarded as the 'Way' (Ac. 9:2, 19:2). It was also known then as the 'Way of Truth' (2 Pt. 2:2), 'Way of Salvation' (Ac. 6:17) and 'Way of Righteousness' (2 Pt. 2:21). Ignatius is acknowledged as the first believer who applied it to self (O. A. Piper, 139). 
Moreover, O. A. Piper (1963:139) stresses that "Christianity is independent of Judaism." It is taught by Jesus as a way of life. It is not an abstract concept, scientific reasoning or philosophy. Those who live according to its system or teachings are called Christians. They are seen as God's people.

Love in Christianity is unconditional. It is not expressed on the basis of one's closeness, relationship, knowledge, appearance, possession and colour. It accepts and treats others with equity, justice, hospitality and friendliness. It is not erotic but clean, morally pure and decent, not boastful, nor prides itself. Besides, it does not rejoice over what is wrong. Rather, it is patient, kind, prudent, builds and does not destroy. It gives hope, encouragement, and strength to the weak, tolerant, accommodates and does not repeal, loves the sinner but hates evil. Consequently, it is described as agape, a reflection of God's love to humanity. It has neither limits nor boundaries (1 Cor. 13:1-13).

According to J. P. Baker (1988:398), love as used in the Old Testament was based on a common Hebrew word, aheb. It was not different from its English connotations. In contrast to this, Greek has several words with difference of meaning relating to love as expressed in diverse situations. Thus, storge means natural affection such as the love between a parent and child, philia for friends and relations or a desire for something, eros is for sexual attraction. In the class of terms describing love, agape was the only word in Greek with no common usage. It denotes "the selfgiving love of God revealed in Jesus Christ."

Therefore, while others are natural, agape is God-like. That is not to say the other three are bad in themselves because they are also given by God. But the problem is that because of sin, they have become excessively or badly destroyed or applied. As a result of this, agape has been completely removed from man. It is only restored through the grace of God by the working of the Holy Spirit enabled by the regeneration of Christ. This is the process of progressive renewal of the believer in God's image (Baker, 398).

Faithfulness is the application of faith. It is the idea of building trust in God. It is an act of obedience, loyalty and commitment to the cause of Christ. It upholds Jesus' teachings and seeks to please the Lord. It is a means of walking with Him. It serves as a common link among Christians and enriches the believer $(\mathrm{Hb}$. 11). Consequently, G. W. Martin ()1988:246 opines that "faith is a quality highly prized in scripture." Hebrews 11:6 sums it up that "without faith it is impossible to please God' (ISV). The entire New Testament, for example, John 14:1, Acts 16:31 charge people to believe and to have faith or trust in God. It is important to practice what one believes. A belief determines a person's attitude and behaviour. It has the idea of a reward for those who diligently pursue it.

Righteousness is the act of conformity with the standard of Christianity. It is neither relative nor subject to an individual's own judgement or personal opinion. It is an act of striving to be good according to set rules and regulations. It brings reward to those who imbibe by it, it blesses and prospers (Prov. 14:34).

N. T. Wright (1988:590-591) declares that righteousness and its related ideas are centred on a Hebrew word sedeq. It is not an abstract concept of justice or virtue. Rather, it focuses on one's right standing and behaviour in a setting.

Holiness is the state of being pure, abstinence from $\sin$ and evil. It does not connote an absolute perfection of the individual in the context of works done by him or her. Instead, it believes that such is imputed absolutely on the believer by the reason of his or her justification through faith in Christ via the personality of the Holy Spirit. However, it does not rule out the personal effort of the individual as being able to avoid $\sin$ or doing wrong. Thus, M. M. Oboh (2021:320) describes this human perspective of maintaining a state of holiness as "... the pursuit of righteousness through faith..."

Thus, S. E. Porter (1993:397) opines that holiness is consequent on the perfect character and behaviour of God demonstrated through Christ for the salvation of humanity. Therefore, believers are to exhibit traits of holiness and purity as they look forward to the second coming of Jesus Christ. However, he holds that a complete state of perfection is not possible for man in the present life.

Man is created with the duty to serve and be productive. He was not to be idle, lazy and negligent. Thus, he is endowed with mental, physical, spiritual, biological qualities and so on needed to enable him execute his task as given or wished to do. This is obvious from God's instruction to the primordial beings Adam and Eve when $\mathrm{He}$ says to them, "Be fruitful, multiply, fill the earth and subdue it" (Gn. 1:28). According to Merriam Webster, to subdue is the process of putting under control by the exertion of the will or force as in the cultivation of a land. This implies an inner ability to achieve an aim or purpose within and outside the individual. Therefore, service is indeed a command from God to man. It has no limitations. Rather, it comprises of the entire gamut of human activities whatever he or she has to do for self or others, religiously, economically, politically, socially or otherwise whether it is formal or informal, official or private concerns.

In view of the above, service ultimately has a corresponding task of accountability which in turn 
attracts the judgement, assessment or evaluation with a reward of commendation or recompense of condemnation of the person so involved as the case may be. This idea is less considered by some people and it has negative impacts in them, others and the society. Consequently, this research is centred on the purpose of raising more awareness, teachings, lessons and implications of service with the goal of improving on human attitude and development towards it. To this end, the method of research is simply descriptive or theoretical in approach using historical, sociotheological analyses.

\section{Historical Background of Mary Bethany and Judas Iscariot}

It is important to do a study of the history and personality of the two individuals: Mary Bethany and Judas Iscariot. This will provide information for the understanding of their places of origin, family background, personalities, characters and dispositions. Meanwhile, there are several misrepresentations or identifications of Mary Bethany with Mary Magdalene. It happens out of error or ignorance. Some easily think that there is only one Mary that is Magdalene in addition to the mother of Christ. Thus, some references to Mary are most of the time mistaken for Magdalene. But Mary Bethany and Mary Magdalene are two different persons entirely. However, both of them were very instrumental in Jesus' ministry and share some common features. Consequently, first, we do an identification of Mary Magdalene as distinct from Mary Bethany.

\section{Mary Magdalene as Distinct from Mary Bethany}

This section begins with a discussion on Mary Magdalene. It is done in order to unveil the differences and misidentification of her with Mary Bethany. The word Magdalene is used as a descriptive term or noun for someone that hails from an area called Magdala. Magdala is an Aramaic word that means a "tower." It was the place referred as Magdala in Matthew 15:39; also known as Dulmanutha in Mark 8:10; located to the Western side of the sea shore of Galilee (D. C. Pellet, 1962:271).

The current location is called Mejdel. It is believed to be the exact preservation and identification of both the name and ancient city. In view of the above, Magdalene is neither a personal name nor a surname of Mary. Rather, it is used as an adjective to identify or qualify her through her name as coming from Magdala. Magdala was used as a reference to a tower because the place used to serve as a guard post. The Greek equivalent of the word at the New Testament time was Tarichea. The city had flourished as a centre of fishing industry. It is a distance of about three miles on the North-Western side of Tiberias (Pellet).
Moreover, the city was well known for its valuable agricultural, shipbuilding and business activities. It was a place of wealth. However, it fell due to the high level of immorality and corruption that brought down its highly prized reputation (E. P. Blair, 1962:288). As a name, Mary is a Greek expression of the Hebrew Miriam (Throckmorton, 1963:628). Furthermore, E. P. Blair (1962:288) asserts that the exact time at which Mary came into contact with Jesus is not precisely known. While it was not shown that Jesus visited the city of Magdala, there are several links to His presence in the surrounding communities ( $\mathrm{Mk}$. 6:53; Mt. 14:34).

Notwithstanding, there is no consensus among scholars as to whether she was the sinful woman Luke in chapter 7 verses 36-50 describes as forgiven of her sins by Jesus and in turn anointed Him with perfume. But she was noted as one of the women from whom Jesus had cast out evil spirits (Lk. 8:2). She had vigil at the grave side of Jesus (Mk. 15:40). He appeared to her after His resurrection (Mt. 28:19; "Mary Magdalene Saint," Furk and Wagnalls New Encyclopedia, mcmlxxv).

Furk and Wagnalls New Encyclopedia also declares that Mary Magdalene had from earliest time be seen as that woman known for her sins who as well anointed Jesus' feet (Lk. 7:33-38). At the same time, she is also linked with Martha's sister who equally anointed Jesus (Jn. 12:3).

E. P. Blair (1962:288) clearly states in his opinion that though seven demons were said to have gone out of Mary Magdalene (Lk. 8:2; Mk. 16:9) and demon possession was usually connected "with both physical and moral spiritual sicknesses, Luke's statement does not offer us much help. Consequently, he opines that the idea of the 'seven demons' could be regarded as emphasis on the severity of her condition (cp. Lk. 8:30). On the other hand, it could be regarded as a reference to the nature of her possession (cp. Lk. 11:26). On the basis of those presuppositions, Blair (288) states categorically that, "There is no solid reason for assuming that Mary had been a harlot and therefore is to be identified with the sinful woman of Luke 7:3650." Besides, it was not in Luke's intention to identify her in this way because he formally introduces Mary Magdalene in 8:2 without the suggestion that she was the one he had alluded in 7:36-50.

Nevertheless, Blair (289) stresses that "Mary Magdalene's 'seven demons' were demons of unchastely. The unsavory reputation of Magdalene may have helped to blacken her character." However, she was strongly devoted to Jesus. This was obvious from her services to Him, which includes her participation in the services of mission activities and journeys around Galilee along with her financial contributions (Lk. 8:1- 
3; Mk. 15:40-41). She was among the entourage that accompanied Jesus to Jerusalem (Mk. 15:41). She was around at the crucifixion (Mk. 15:40; Jn. 19:25) plans to anoint the body of Jesus at the tomb (Mk. 16:1; Lk. $23: 55 ; 24: 1)$, gives a report of the empty tomb after the resurrection of Jesus and presents the angel's message to the disciples (Lk. 24:1-11), finally, she saw the personal appearance of Jesus after His resurrection (Jn. 20:11-18).

\section{Mary's Life and Family Background}

E. H. Palmer (1986:268) agrees that Mary Bethany is indeed easily mistaken for Mary Magdalene. But this Mary is "the sister of Martha and Lazarus, who lived in Bethany". She is noted for her sense of contemplation. She sat at the feet of Jesus when He visited their home to listen intently to His teachings (Lk. 10:38-42). She was complimented by Jesus for doing this. Moreover, she was deeply devoted to Him by anointing Him lavishly with an expensive perfume at the home of Simon the leper in Bethany (Mt. 26:6-13; Mk. 14:3-9, Jn. 12:1-8; Palmer). Robert H. Mounce (2011:239) observes that "it may be that Simon was the father of Lazarus and his sisters." That is Martha and Mary. This assumption has no strong possible evidence. However, there are indications that show that Jesus and the disciples were familiar with Lazarus' family. An example of this is the information Jesus gave to them about Lazarus sickness, his subsequent death and there expected visitation to the family as well as the plan to raise him back to life. Jesus even addresses him as a friend:

Now a certain man was ill, Lazarus from Bethany, the village of Mary and her sister Martha. Mary was the woman who anointed the Lord with perfume and wiped his feet with her hair. Her brother Lazarus was the one who was ill. So the sisters sent word to Jesus and told him, "Lord, the one whom you love is ill." But when Jesus heard it, he said, "This illness isn't meant to end in death. It's for God's glory, so that the son of God may be glorified through it." Now Jesus loved Martha and her sister and Lazarus. Yet, when he heard that Lazarus was ill, he stayed where he was for two more days. After this, he told the disciples, "Let's go back to Judea."... Then after this, he told them, "Our friend Lazarus has fallen asleep, but I'm leaving to wake him up." ... Then Jesus told them plainly, "Lazarus has died for your sake I'm glad that I wasn't there, so that you may believe. But let's go to him." (Jn. 11:1-15; ISV).

The flow of conservation between Jesus and His disciples as shown above is inherent with the fact that the disciples were quite familiar with Lazarus and his family members. Thus, if Simon the leper was their father, the disciples and possibly John would have alluded to it at some points. But at no time were such ever referred in the gospels. Moreover, if none would and as usual with Luke who is known for not giving attention to the centrality of issues, he is excusable if at all it were true. But not with John who gives minutes details as much as he would in some or most of his presentations. Besides, the location of Simon's house where the incident occurred at Bethany being the same city where Mary lives is also not enough for this assumption. It is even the more reason why Matthew would have made mention of it if he was.

Besides, the way in which John gives his narrative at this point:

Six days before the Passover, Jesus arrived in Bethany, where Lazarus lived, the man whom Jesus had raised from the dead. There, they gave a dinner for him. Martha served, and Lazarus was one of those at table with him. Mary took a litron of expensive perform... (12:1-3; ISV).

Without the mention of the host's name especially if he was the father further strengthens the view that the host, Simon could really not have been. It is observable too that John did not bother his audience neither with the name of the host or the concept of being the father and head of the home in spite of his familiarity with them.

But there is something special here that is, it appears the banquet or ceremony was an arrangement of the friends and devotees of Jesus in Bethany. It was not necessarily by Lazarus and his family members who were also guests and was with Jesus on the table while his sister Martha was one of those who served. This is the second time we see and hear a mention and record of Martha as serving at meals (Jn. 12:2). The first was with Luke 10:40. In addition to the fact that it buttresses the apostles' familiarity with this family, it further strengthens Martha's character as one committed or gifted in service. This she uses to the best of her ability. Wherever she was, she gives herself to meeting the needs of others.

\section{Karl Burger (1953:225) clearly states that Mary Magdalene was}

"The most devoted of the female followers of Jesus. She has been confused with the two other persons mentioned in the New Testament; with the "woman... which was a sinner' of Luke vii $36 \ldots$ by reason of which she was supposed to have been of profligate character, and with Mary of Bethany.

He attributes the reason behind the errors to be likely due to the mention of her name in Luke 8:2. He also asserts that this assumption is not correct because 
of the statement in verse one. However, he expresses further that though it appears to be in verse 2 and in Mark 16:1, also that she was healed of a mental problem by Jesus but Mary of Bethany was known to have come from a respected family living closer to Jerusalem. She was also always in the company of her immediate family. But in contrast to this, "Mary of Magdalene belonged to a place in Galilee (Matt. xv. 39)." Nevertheless, Burger claims that an ancient story portrays her as being "in league with Lucifer until Jesus appeared and affected her conversion." Therefore, he cautions that the time has come for her to be disassociated from what she is not and be given her rightful place as one that was devoted to Jesus.

In the same vein, B. H. Throckmorton (1963:629) informs that Mary Magdalene was treated of evil spirits and infirmities. To this end, she had seven demons cast out of her (Mk. 16:9). This perhaps is an indication that her case was very serious (Mt. 12:45; Mk. 5:9). But he went further to state that, "A questionable tradition identifies her with the unnamed sinful woman who anointed our Lord (Lk. 7:37), and she has thus been regarded as the typical reformed 'fallen woman."'

\section{Argument about the Identity of the Sinful Woman in Luke 7:37ff}

At this juncture, it is clear that there are three women that are being mistaken or identified with one another. While it is distinct as to the two of them that are different from each other, which are Mary Magdalene and Mary Bethany, the identity of the third, that is the woman designated as being forgiven by Jesus in Luke 7:36-50 is not quite certain. Nevertheless, the assumption by Blair to attribute Mary Magdalene's demonic influence merely to be unchaste does not indicate that she could not have been worse in her state of $\sin$. In other words, the term in itself does not reduce the degree of an individual's attitude or propensity toward sin or what is bad. Rather, it is enough description of the appalling nature of one's disposition toward an act or practice that is repudiated.

Instead of the belief that, "The unsavory reputation of Magdala may have helped to blacken her character" as Blair views it (289) does not actually exonerate her. Much more, that seven demons were cast out of her by Jesus alone portrays the extent of the negative influence that the city as a result of its strong decadence of immorality weighs on her. This is more probable than Blair's assumption. Above and beyond, Blair leans more to this idea when he harps that the seven demons driven out of her could be seen as depicting the severity or nature of her demonic status. Demonic possession is not for pleasure or good. It ruins the fortune and anything good in an individual. It makes a person's character and attitude to run counter to the expected norms and value of a religion or the society in order to destroy his or her reputation. Consequently, it could not have been to the wellbeing, pleasure or good of Mary Magdalene for her to have been possessed of the seven demons that were cast out of her by Jesus.

Notwithstanding, that Mary Magdalene was thus delivered from her demonic possession and its impact on immorality does not limit her from being radically faithful, obedient and committed to the point of her admired devotion to Jesus. This is one of the beauties of salvation and its corresponding healing and strength on an individual. The conversion of Paul (Saul) from his former state of the persecution of believers to being one of them and himself being persecuted is just one of such innumerable instances (Ac. 7, 8, 9, 11, 12, $13,22,26)$. Therefore, her subsequent life of chastity, value, integrity and dignity speaks volume of the genuineness of her healing, conversion and faithfulness. The association of her past in comparison with her latter life is not intended to cast aspersion on her. Moreover, it serves to appraise her for what it takes to follow and serve the Lord, the worth of Christianity, and to appreciate Christ for His role in the transformation of humanity. However, that is not to assume that one should be stigmatized when he or she does not deserve it. What is being argued here is that if it is real, being a condition of her past life, reference to it in the present circumstances is not of condemnation but of her reputation in changing positively from it in the way she did.

\section{Proof of Mary Bethany as the Sinful Woman in Luke 7:37ff}

On the basis of the previous discussions, it is clear that Mary Magdalene was not the woman involved in the anointing of Jesus at Bethany or around the city of Nain. Her attempted involvement in His anointing was after the crucifixion at the grave side (Mk. 16:1; Lk. 23:55-24:1ff). Mary of Bethany has more resemblance to the woman whose sins were mentioned to have been forgiven. However, every believer's sins are forgiven by Jesus. The idea of the "woman whose sins were forgiven" is a mere designation of her simply as a means of identification in this case (Lk. 3:36-50). On the other hand, Mary of Bethany shares several other things with her for example, both incidents of the anointing happened when Jesus was visiting in a house (Mt. 26:7; Lk. 7:36; Jn. 12:1), a large quantity of perfume was used for this anointing (Mt. 26:7; Lk. 7:37; Jn. 12:3), it was poured lavishly on Him (Mt. 26:7, Lk. 7:38; Jn. 12:3), the woman uses her hair to wipe and dry His feet (Lk. 7:38; Jn. 12:3) and there were elements of accusation at both instances (Mt. 26:8-9; Lk. 7:39; Jn. 12:5, 7). The encounter occurs around Judea. Bethany was referred (Mt. 26:1; Jn. 12:1) and the other in Nain (Lk. 7:11).

Moving away from the location, Simon is given as the name of the host in both narratives. Simon 
the Pharisee (Lk. 7:36, 37, 39, 40) and Simon the Leper (Mt. 26:6, Mk. 14:3). While it is clear that religiously, he was a Pharisee, leprosy possibly describes his health condition of which he must have been cured by Jesus giving rise to the relationship. Nevertheless, the occurrence of the prevalence of more of its similarities being far more than the differences as shown above, would suggest that Mary of Bethany, sister of Martha and Lazarus was the woman especially designated as forgiven in Luke 7:37. To this end, it is interesting to note too that Luke nowhere else provides a different account of such encounter leading to the anointing of Jesus. The same is true of Matthew, Mark and John.

Furthermore, Throckmorton argues that, it was John who in his gospel links her with the unidentified but fallen (sinful) woman that anointed Jesus (Mk. 14:3-9, Mt. 26:6-13, Lk. 7:36-50; 628). In addition, he claims that, "Nowhere in the synoptic is it even implied that the name of the woman was Mary" (628). Notwithstanding that her name was not specifically mentioned does not rule out the fact that she could not have been the woman so referred. Moreover, Mark situated the incident in Bethany (Mk. 14:3). The same trend was followed by Matthew (Mt. 26:6). It was only Luke who did not locate the incident as having happened in Bethany but with no clear cut identification seemingly to be in Nain which is the last name of a place mentioned by him before the narrative (Lk. 7:11). This view strongly supports Mary Bethany as being the fallen or sinful woman instead of Mary Magdalene. This position is strengthened by S. S. Smalley's submission in the following discourse.

S. S. Smalley (1982:747) puts forward an idea of a school of thought that is decisive and convincing of who the fallen woman represents. However, first, he reiterates some earlier ideas saying that "All four Gospels contain an account of the anointing of Jesus by a woman (Mt. 26:6-13; Mk. 14:3-9; Lk. 7:37-50; Jn. 12:1-8)." Nevertheless, he was quick to note that there is difficulty in deciding whether all refer to a particular incident, woman or how many women were involved. He believes that Matthew and Mark versions possibly agree. But Luke's account he says, differs largely because he puts the happening as having taken place in Galilee at a time when John the Baptist was in prison instead of Bethany not long before Jesus' death.

All the same, John was the only one that gives the name of the woman, Mary, Martha's sister. Similarly, it was only Luke who adds that the woman was a sinner (7:37). Both Matthew and Mark put the scene as specifically:

In the house of Simon the leper; and Matthew and Mark agree against Luke and John that it was the head and not the feet of Jesus that the woman anointed.
There have been various attempts to resolve those differences. One is to suggest that Luke describes a different occasion, but that it is the same woman who performs the anointing... yet John could not have been unaware of the real identity of the two Marys or be content to confuse his readers.

This indeed is another strong reason to believe that the sinful woman refers to Mary Bethany as this research upholds.

In view of the above, a noteworthy aspect of this section among other things is the discovery that Mary Magdalene is not the same with Mary Bethany. Neither also was she the woman whose sins were forgiven. However, Mary Bethany has more in common with the latter. This paper thus, situates her in this manner.

Consequently, Blair (289) alludes to the stories of the anointing as it concerns Luke 7:36-50 and seeks to know whether it is one of the same events with others or not. Nevertheless, he concludes that "in any case, Mary of Bethany figured in one to her eternal credit (Mark 14:9)!" Within the context of these propositions, Blair nonetheless argues that

Luke's location of the home of the sisters in S. Galilee (Luke 10:38; 13:22; 17:11) rather than in Bethany near Jerusalem, is no argument against the identification, since Luke's whole central section is loosely arranged chronologically.... (289).

This assertion is surprising because Blair earlier denies Mary Bethany as being the one rendered by Luke 7:36-48. Yet, to acknowledge as he does above about Luke's pattern of presenting his discourse without accepting the notion of the identity of Mary Bethany with his account of the sinful woman runs counter to his claim. In addition to the views previously shown in support of this belief, one is of the opinion that Luke's failure to address the woman by her name but to simply declare her as sinful is very much in consonant with Blair's portrayal of his style. Therefore, what plays out in Luke's usage of the term 'sinful woman' should be seen as a matter of semantics, choice of words and expressions, emphasis and intent of purpose as he perceives of her and wishes his audience to know. Besides, Lukan's episode or story of the woman if it is separated from the accounts of the other apostles is found in nowhere else other than his. He alone could not have been privy to this event which was not the case as the incident was never in secret. The other disciples and several persons including the host were all present (Lk. 7:49). That Luke alone chooses to convey her in this manner is therefore, indeed simply a matter of his 
choice whatever it may be and style that is already obvious about him.

Another evidence to correlate this opinion is found in the intrinsic or applied similarities in the content of Luke 7:37-38 and John 11:2:

There was a woman who was a notorious sinner in that city. When she learned that Jesus was eating at the Pharisee's home, she took an alabaster jar of perfume and knelt at his feet behind him. She was crying and began to wash his feet with her tears and dry them with her hair. Then she kissed his feet over and over again, anointing them constantly with the perfume;

Mary was the woman who anointed the Lord with perfume and wiped his feet with her hair. Her brother Lazarus was the one who was ill (ISV).

From these two references, John's report answers the question of what was lacking in Lukan's account as to the name of the woman. This account states that a notorious sinful woman anointed Jesus. But John filled the missing link or gap which is her name by stating that, "Mary was the woman who anointed the Lord with perfume." He also added just as Luke expresses that she wipes His feet with her hair. Moreover, for a clearer understanding of the identity of the woman, he adds further that, "her brother Lazarus was the one that was ill." These are statements of emphasis to establish a fact. The fact is that Mary, Lazarus' sister is the woman so designated as sinful in the Luke's account of the anointing of Jesus. The fitness of the text is natural with the divine inspiration of Scriptures. In view of the additional arguments as put forward in this section, it is succinct enough to reiterate more and more that Mary of Bethany is the character in the whole four gospels anointing accounts of Jesus.

According to Macalister (1963:98), Bethany is a village with a distance a little above a mile (1 5/8) from Jerusalem (Jn.11:18). It is situated along the road from "Jericho, close to Bethphage and on the Mount of Olives" (Mk.11:1; Lk.19:29). It used to serve as a lodging place for Jesus when $\mathrm{He}$ is in Jerusalem (Mk.11:11). Mary, and her siblings, Martha and Lazarus lived in it. This was the place where Lazarus was raised by Jesus from death having being buried for three days. Simon the leper in whose house Jesus was anointed by a woman (Mary), lived in it (Mt.26:6; Mk.14:3). Jesus' ascension also occurred here in Bethany (Lk.24:50).

Birdsall, J. N. (1986:137) confirms the distance of Bethany from Jerusalem as $3 \mathrm{~km}$, similarly on the way from or to Jericho. Because of its identification as the home of Jesus' beloved friends, Mary, Martha and particularly Lazarus it has earned a modern name el-Aziriyeh, the home of Lazarus. Birdsall also agrees with Macalister that it was the place Jesus was anointed. However, he adds that, this incident was "its most central role in the Gospel history..."

In K. W. Clark's (1962:387) view, Bethany as a term means "house of Ananiah or house of the poor, afflicted..." He holds the same opinion as Macalister and Birdsall that its distance away from Jerusalem is a little over a mile (1 5/8) to the East and on the Eastern slope of Mount Olives. Jesus and His disciples were known to lodge in Bethany each time they attended the Passover ceremonies (Mt.21:17; Lk.21:37; Mk.11:19). He was used to taking the path that leads through the sites of the Mount Olives. It was also the way He took during His triumphant entry into Jerusalem (Mk.11:111 and its parallel).

Bethany's name, el-Aziriyeh was given to it by Muslim inhabitants who believed in Lazarus as a saint. Nevertheless, "Both Muslims and Christians have marked many sacred sites in this little suburb" (Clark, 388). A traditional crypt belonging to Lazarus was discovered by some pilgrims early in $333 \mathrm{~A}$. D. Also, before $385 \mathrm{~A}$. D, a portion has been identified as the "spot where Mary met the Lord." It has been enclosed in a church built around it far before the aforementioned year. By the same time, a church has been built on the crypt as well. Moreover, as at the eleventh century, a basilica has been constructed to mark the spot at which the anointing of Jesus' feet was done by Mary. It was later reported by Abbot Daniel as being to the East of the crypt (Clark, 388).

H. G. Anderson (2009:567-563) presents a discourse that corroborates among others, earlier views on Bethany's location, meaning and distance from Jerusalem as well as Jesus' presence, activities and His connection to the three siblings, Mary, Martha and Lazarus. Anderson also shears the opinion that it "served as Jesus' abode when in JUDEA (Matt.21:17; Mk.11:11)." He posits that the name el-Aziriyeh is translated as "the place of Lazarus." Moreover, the traditional location of the tomb of Lazarus is marked in it.

\section{Judas Iscariot's Life and Family Background}

Much is not known about the life and family background of Judas Iscariot. However, he was one of the twelve Apostles of Jesus Christ (Lk. 6:16; Ac.1:13; D. Smith and W. Foster (1963:535). D. Smith and W. Foster (1963:535) report that the term Judas in Apocrypha is the Greek equivalent of the Hebrew name Judah. R. P. Martin (1982:634) explains that Iscariot applied to his name is a Hebrew derivation of him as a man from Kerioth which is the name of a place located in Moab. It can also be linked to another place called Kerioth-Hezron (Jo. 15:25). It is an area $19 \mathrm{~km}$ south of Hebron. It is regarded as being more likely as his 
designation because it is a word (kerioth-Hezron) derived from an Aramaicized reference to an assassin (cf. Ac. 21:38). Martin also describes him as the apostle whose name always appears last on the list of the apostles.

T. S. Kepler (1963:535) stresses that Judas Iscariot "is the only Judaean disciple..." Moreover, "Judas is the Greek form of Judah..." According to G. W. Buchanan (1982:1151), Iscariot is not the name of Judas' father. Rather, his father's name is called Simon (Jn. 6:71; 13:2, 26). There are several suggestions of the meaning of Iscariot. The most popular among them are 'man of Kerioth,' 'a liar' or 'a man who lies,' a dyer and 'one who bears a dagger.' Thus, Kerioth qualifies him as an indigene of Kerioth. Nevertheless, the usage of it by Luke 22:3 portrays it somehow as a nickname. Apart from Judas there was no other disciple that was described or linked by his name to his place of origin.

By the term a liar, he is described as a traitor. This can be compared to the action of one of David's closest men who betrayed him at the time he became tired and weary in the night. The man (Ahitophel) like Judas also committed suicide (2 Sa. 16:15-17:2; Mt. 27:3-5; Buchanan, 1151).

Some scholars are of the opinion that Iscariot means a dyer. This "refers to an occupation of dyeing cloth" (Buchanan, 1151). Being a dagger bearer, Iscariot may be used as a semitic word suggestive of sicarius which is a dagger (sica) or an assassin. At the time of Jesus, there were extremely zealous Jewish nationalists in Palestine called sicarii because of their usual attitude of carrying daggers in their under cloths or cloaks. They were doing this in order to aid them in taking advantages at every available opportunity to kill their Roman enemies. Nonetheless, Buchanan informs that the four Gospels, Acts and 1 Corinthians 11:23 are the only sources available for the treatment of the life of Judas Iscariot (1151-1152).

\section{Mary and Judas Encounter and Services to Jesus}

Mary's devotion and commitment to Jesus contrast widely with that of Judas. However, they both have encounter and some relationships with Jesus whose contents are necessary for the understanding of their individual perspective of Him and how that affects their union, dependence, services and regard as well as the consequences of these on them.

\section{Mary's Encounter and Services to Jesus}

Smalley (747) provides the hint that Mary's encounter with Jesus began at a point after the return of the seventy (Lk. 10:17. 32-42), in Bethany (Jn. 11:1). Irrespective of the time, record shows from this very time onward that her life was never the same. Jesus' transformation brought tremendous impact into her life. She avail herself of the privilege with remarkable efforts. Thus, her works singled her out among the early followers of Jesus as an exemplary believer. She was greatly commended for her trustworthy services and recommended to be so remembered by Jesus.

\section{Mary's Act of Service as Expression of Right Choice, Contemplation and Beauty \\ Mary stayed to listen attentively to Jesus'} teaching in their home (Lk. 10:39) She was described by Him as having chosen what was better for her (the knowledge and presence of God, Lk. 10:42) she anointed Jesus (Jn. 11:2; Smalley, 747).

By virtue of her listening attention to Jesus while her sister "Martha was busy as a hostess (Lk.10:38-42),” E. H. Palmer (1986:268) qualifies her as a woman with a contemplative nature. It was a year after this encounter, that Lazarus her brother died. She stayed at home at the visitation of Jesus to commiserate with them but Martha went out to welcome Him (Jn. 11:20). It was during another of Jesus' visit to Bethany that she further expresses her devotion by anointing him with perfume (Jn. 12:1-8).

Her deep sense of devotion to Jesus was acknowledged by Matthew, Mark and John (Mt. 26:613; Mk. 14:3-7. Jn. 12:1-8). Judas including the other disciples "objected to such extravagance as a waste, but Jesus defended her action as a "beautiful thing" (Mt. 26:10), stating that it would be remembered whenever the gospel are preached" (Palmer, 268).

D. A. Carson (1974:117) harps on the cost of the perfume as John records that it is approximately the worth of a year's salary for a work man (Jn. 12:13). Nevertheless, Jesus rebukes the disciples for troubling Mary. He accuses them of bothering her. They call her action a waste, whereas to Jesus it was beautiful. The distinction of the action of the woman and the reaction of the disciple is an implicit idea of Christology that shows that He knew ahead of time His impending death and departure from the world. Furthermore, that as $\mathrm{He}$ was indeed truly "gentle and humble in heart" (11:20), he deserves this lavish outpouring of love and expenses."

However, Carson (117) expresses that, the anointing does not depict Jesus as the Messiah what it does is only to prepare Him for His "burial after dying the death of a criminal, for only in that circumstance would the customary anointing of the body be omitted." Nevertheless, Jesus' defense of Mary does not necessarily mean that she understood what she did in this regard. 
Mary's Act of Service as Expression of Love and Passion for Spirituality

Blair describes Mary's commitment to Jesus as one of a loving relationship. This is pictured in Luke 10:38-42 and John 11:1-12:8 (289). Moreover, he sees her as a:

Contemplative type, somewhat indifferent to mundane matters, single-mindedly absorbed in the truth about the kingdom of God and its inaugurator. The Johanine stories picture her as grieving uncontrollably over her brother's death (Jn. 11:20, 31), as deeply devoted to Jesus and cognizant of his power (vs. 32), and as effusively thankful for the superlatively wonderful restoration of the brother from the dead (12:1-3), (289).

Blair also posits the prevalence of some inherent problems in the anointing stories as Mark 14:39 and John 12:1-8 present. While Mark claims Mary poured her perform on the head of Jesus. John reports that it was His feet. Other apparent issues are to determine the motive behind the anointing, the circumstances surrounding it such as the time, place and persons that were present as well as "the literary relationship of these stories to the anointing recorded in Luke 7:36-50; and the like." (289).

Blair appropriately asserts the obviously agreed idea which believes that

Mark is correct in asserting that Jesus' head was anointed by Mary probably as her grateful ascription to him of royal dignity. Jesus reinterpreted the act in the light of his premonition of coming disaster and declared it an anointing of his body "beforehand for burying" (Mark 14:8). (289).

Mary's Acts of Service as Expression of Faith, Affection, Respect and Appreciation for Jesus

According to Matthew Henry (1972:1339) the manner at which Mary anointed Jesus with her expensive ointment, pouring it on Him right from the head would be regarded as "a strange sort of compliment." Nevertheless, it was attributed to her as "the highest piece of respect." Consequently, it serves to show her level of faith, love and respect for Jesus Christ.

Matthew does not argue whether Mary Bethany is actually the woman that was involved in the anointing of Jesus in Luke's account 7:37ff. Rather, he simply expresses the opinion that some believed she was and draws a meaning from this belief by saying that,

Some think that this was she who loved much at first, and washed Christ's feet with her tears (Luke vii. 38, 47). Where there is true love in the heart to Jesus Christ, nothing will be thought too good, no, nor good enough to bestow upon him (1329).

Thus, Matthew agrees in principle that Mary was the woman in Luke's account. Moreover, her deep love, honour and commitment to Jesus are not without her value and appreciation for what Jesus had done for her. So, if Jesus had first loved her so much that $\mathrm{He}$ forgives, delivers and saves her in spite of her notorious and enormous sins or larger debt (Lk. 7:39-47), it was not out of place for her to have so appreciated much to the extent of crying and washing Jesus' feet with her tears and to dry them with her hair being the pride of a woman, blessing and anointing them with perfume.

\section{Mary's Acts of Service as the Kindness of a Good Woman}

Matthew (1339) further notes that as against her condemnation by the disciples who took offence at her, Jesus approbates and commends her as the kindness of a good woman. Specifically, Jesus refers to it as "a good work" (Mt. 26:10). Other versions such as ISV (International Standard Version), portrays it as "a beautiful thing," and "a noble thing," CSB (Christian Standard Bible). Along with this, Jesus praises her "than could have been imagined." He also deepens the import of her deed as being a preparation for His burial (v.12), and that the memorial of it shall be in her honour (v. 13). Thus, "The memorial of this woman was to be preserved by maintaining her faith and piety in the preaching of the gospel.

\section{Mary's Act of Service as Giving of Attention and Expression of Value and Worship \\ Neil S. Wilson (1991: 1591) views Mary as} someone who sees hospitality from the perspective of "giving more attention to the guest himself than to the needs he might have." Thus, she prefers to talk than cook, more interested to listen to the words of her guest than to get involved in the cleaning of her home" or the timeliness of her meals." Her approach to the events around her shows her as a person who is mainly a "responder." She prepares little but participates in much. At a point earlier in Jesus visit to their home, it became obvious that her weakness was for her "to learn that action is often appropriate and necessary." But when she was accused of this by her sister, Martha for staying away while she alone does the cooking, Jesus defended her with the statement that her "choice to enjoy his company was the most appropriate response at the time" (Lk. 16:38-42). Thus, one's weakness at a point could sometimes be a source of strength, not to scheme for evil but to do what is right.

She appears later and last "to have become a woman of thoughtful and worshipful action" (Wilson, 1591). Unlike before, "she was at Jesus' feet, washing them with perfume and wiping them with her hair" 
(1591). Similarly, she understood better, the reason "why Jesus was going to die (1591). He credits it to her honour and memorial being an example of a costly service (1591).

Consequently, her strength and accomplishments present her as the only person who perhaps understood and accepted Jesus' approaching death. As a result, she took time to anoint His body while $\mathrm{He}$ was still living. Obedience and service rendered at an instant irrespective of size could have a widespread effect.

\section{Mary's Act of Service as Timely, Discernable, Deep Devotion and Honour for Jesus}

William Macdonald (1995:1300) perceives of Mary's action as a welcome development and relief to Jesus as against His suffering from the persecution of the priests, the disciple's pettiness, and disloyalty of Judas. The high cost of the sacrifice (perfume) expresses her deep devotion for Jesus. He commended her and describes it as beautiful, sided her against the attack and distorted thinking of the disciples particularly Judas who considers it as a huge waste. Moreover, Jesus regards it as timely.

Macdonald further stresses that Mary's action was prompted by her sense of discernment. She seized the opportunity of what others could not see. She believes in the Lord's prediction of His death. She felt it was the appropriate time for the anointing or never. Her belief and action proved through when the woman who wanted to anoint His dead body came to the tomb only to be welcomed by the evidence of His resurrection (Mk. 16:1-6). By her good action, she was immortalized. It makes an indelible record in Jesus' memory (1300).

Among other views similar to the ones earlier noted concerning the relevance, reward and worth of Mary's action on Jesus, Robert H. Mounce (2011:239) marvels that the disciples could not see the "deeper meaning in the generous act of the woman and reacted accordingly." He also describes the pouring of the oil on Jesus' head as symbolic of His kingship (2 Kg. 9:6).

Jeannine K. Brown (2015:293) also raises a surprise as to Mary's knowledge of Jesus' mission in her preparation for His burial (26:12) as against the ignorance of the disciples who were more privileged and privy to this passion prediction. Four times they heard of His coming death. Yet, they could not make something out of them (Mt. 16:21, 17:22-23; 20:17-19; 26:1-2).

J. C Ryle (1993:250) opines that there is no doubt that Mary's action was motivated by her reverence and affection for Jesus as a result of the soul- benefit she received from Him. For her, there was no amount of honour too costly to be bestowed on him in return. Jesus' prediction for her good deed is being fulfilled on a daily basis (v. 13). Thus, her action is known wherever the gospel is read and her popularity keeps growing and increasing.

In contrast to her,

The deeds and titles of many a king and emperor and general are as completely forgotten as if written in the sand; but the grateful act of one humble Christian woman is recorded in 150 different languages, and is known all over the globe. Honour praise last only a few days: the praise of Christ endures forever. The path way to lasting honour is to honour Christ (251).

With the growing awareness of Christianity and the translation of the Bible into several local languages the number keeps increasing along with her fame and honour.

\section{Mary's Act of Service as Extraordinarily Costly and Good}

Craig S. Keener (1953:119) notes that the act of anointing important guests on the head was customary to the Jews. But Mary's anointing of Jesus though in the trend of custom was extraordinary. For instance, the perfume she used was without doubt imported from the East. D. A. Carson ("Matthew," 1994:117) situates the ingredient of the product from a hard plant found in India. Meanwhile, Keener also adds that it was expensive and has the value of a laborer's annual wage. "Its fragrance was preserved by its sealing in alabaster (the favored container for perfume). Once the flask was broken, its contents must be used with their full freshness only once (119).

Besides, he posits that, it was "probably been kept in her family as an heirloom" (119). If this assertion is taken then it could follow that there was an agreement at the family to have it used the way she did. But this was not the case. In addition, there would have been reactions from the family members. Therefore, it could not have been a family property.

On the other hand, the response of Jesus to Mary's accusers to stop troubling her, that she has done something beautiful to Him does not suggest that she was not alone in her decision to anoint Him and the ownership of the perfume. Moreover, the commendation, reward, honour and commemoration were directed at no one else but her (Mt. 26:8-13).

With regards to the source and still on the ownership of the perfume, its expensive nature should not cause a doubt as to whether this woman, Mary was in a position to have acquired it or not. Bethany though a small community in relation to others, can be a place 
of wealth with the involvement of God in it. Thus, with the original meaning of the name (Bethany) probably serving as a reflection of the economic status of its inhabitants as the house of the poor and afflicted (Clarks, 387), notwithstanding, a serious entrepreneur can make a difference of business and possessions in some ways in it. The following idea provides a clue to this belief.

Probably, with no mention of anyone else except herself, the sister Martha and brother Lazarus, it is possible they were orphans and indigent. Hence, Mary had gone into promiscuity, prostitution or other acts of sins from which she was delivered and rehabilitated by Jesus. It was as a result of this knowledge of her past life as have been set out in this work that, she was designated as a sinful, notorious sinner (Lk. 7:37ff). It was for the same reason that the Pharisee who invited Jesus had an insinuation about her. "If this man were a prophet, he would have known who is touching him and what kind of woman she is. She's a sinner" (Lk. 7:39; ISV).

The above presuppositions believe that as part of her rehabilitation, she might have been sponsored, assisted, funded or established by Jesus to run an enterprise dealing on the sale of perfume. She would have had tremendous progress. Her business possibly would have involved importation of perfume as well. No wonder the particular product for the anointing of Jesus must have been specially sought for by her with the evidence that it was a product, an importation from the East. With her position and success in this regard, she had the advantage and means to acquire the oil in addition to her willingness to lavishly appreciate Jesus. Consequently, Jesus' response to Simon is a valid support to this opinion:

Then turning to the woman, he told Simon, "Do you see this woman? I came into your house, you didn't give me any water for my feet, but this woman has washed my feet with her tears and dried them with her hair... You didn't anoint my head with oil, but this woman has anointed my feet with perfume. So I'm telling you that her sins, as many as they are, have been forgiven, and that's why she has shown such great love. But the one to whom little is forgiven loves little. (Lk. 7:44-47; ISV).

\section{Mary's Act of Service as Expression of Comportment, Restrain, Submission and Total Trust in God}

Robert H. Gundry (2010:115) stresses that Jesus' caution to the disciples, "why are you causing the woman trouble," could imply that they were bothering "her with indignation or voicing to one another their indignation in her hearing..." Going by this opinion, it is important to note that in spite of what she suffers from them, she never reacted. Rather, it was Jesus who intervenes on her behalf. Thus, she did not allow the activities, criticisms, insults and abuses of her accusers, distracters and of course, her enemies, those who hated her to discourage or distract her from her good work. She continued doing what she knew and believed was in the Lord's interest no matter the trouble she had.

Besides, Gundry (208) also opines that the perfume Mary used was the best of perfumes, unadulterated nard. The significance of this as well as its expensiveness is that it enhances the honour she bestows on Jesus. Furthermore, Mary breaks the flask to pour out the perfume on Jesus while this punctuates the unexpected lavishness of its content, it also portrays her intention not to have it used for anything else, thereby symbolizing the completeness of the outpouring. It is worthy to note too that, it is evident of Mary's complete devotion, honour, submission and her total trust in Christ. Thus, she does not consider it any more relevant for it to be used thereafter (Mk. 14:10, 14:20; Jn. 6:17; $12: 14)$

\section{Judas' Encounter and Disservice to Jesus}

The relationship between Judas and Jesus started when the latter extended a call to him to become one of His disciples (Mk. 3:19; Lk. 6:16). Thus, he was "One of Jesus' twelve disciples" (Buchanan, 1151). He was a treasurer in the apostolic group (Jn. 13:29). John pictures him as a thief (Jn. 12:6). Furthermore, Martin stresses that the Johanine view is based mainly on a presupposition that, he pilfered the money that was kept in his care (12:6). So the gospel story is replete with his havoc. Hence, he was usually given a common descriptive tag as "one of the twelve" being an undignified recognition due to his dubious character (Mk. 14:10, 20; Jn.6:71; 12:14).Consequently, Judas activities are better described as disservice rather than service.

\section{Judas Criticizes Mary}

Judas criticized Mary for anointing Jesus (Jn. 12:3-5). Thus, he did not see what was good in the beautiful deed praised by Him (Mk. 14:6). The only thing he sees in it was about how it could have been used to increase the income of the apostles and in turn for him. Nevertheless, his personal interest was shrouded with the disguise of appealing on behalf of the poor. Consequently, Judas had covetous and deceitful character (Martin, 134).

\section{Judas Plots Jesus' Betrayer}

Immediately after the incident of anointing at Bethany, Judas goes to the high priests to negotiate the process of Jesus' betray (Mt. 26:14-16, Mk. 14:10-11; Lk. 22:3-6). They promised to pay some money to him (Mt. 27:9). Luke opines that Satan was behind the treachery of Judas for he enters and inspires him towards it. John shares a similar view as well (Jn. 13:2, 
27). The synoptists, that is, Matthew, Mark and Luke all "agree that Judas determined to await a favorable opportunity when he might deliver Jesus up to his enemies 'privately,' secretly, by craft..." (Lk. 22:6; Mk. 14:1-2; Martin, 635).

Jesus had prophetic insight into Judas planned betrayer in his presence at the table (Mt. 26:25). Therein, He made a final appeal to him to desist but he refused. Thereupon, Satan took control of him. He went out into the night (Jn. 13:27-30). His accomplices had advantage of the time and carried through with their already arranged plan to arrest Jesus. Thus, Judas' betrayal became evident at Gethsemane as he led the soldiers to arrest Him while praying (Mt. 14:43). "The sign of identification was the last touch of irony. 'The one I shall kiss is the man' and with that the traitor's work was completed" (Martin, 635).

\section{Judas's Unrepentant Remorse and Wrongful Choice}

The last of Judas' life was beset with much difficulty. He had a pathetic remorse of which he committed suicide (Mt. 27:3-10), in a place called Hakeldama (The field of blood) he bought with the proceeds of his crime against Jesus (Ac. 1:18-19; Martin, 635). Martin (635) also provides information that Judas died on his own land. He got swollen in it. Before his death, he hung on a rope, it cut and he fell headlong and got killed. Thus, Judas' fate was his choice. He goes as he chooses to undo himself from the gospel ministry (Ac. 1:25).

\section{Judas Bedeviled by his Multiple Negative Characters and Unbelief}

Martin (635) gives more insight into Judas characters, failure and doom by seeking to understand his motives. Thus, he tries to make out something that may help in getting a clue or near description of Judas's enigmatic nature or reasons behind his actions. To this end, he says,

Psychological studies are indecisive and not very profitable, love of money, jealousy of the other disciples; fear of the inevitable outcome of the Master's ministry which made him turns state's evidence in order to save his own skin, an enthusiastic intention to force Christ's hand and make him declare himself as Messiah - de Quincey's famous reconstruction, a bitter, revengeful spirit which arose when his worldly hopes were crushed and this disappointment turned spite and spite became hate - all these motives have suggested.

To this end, he expresses that, as a starting point, the sincerity of Jesus' call to Judas cannot be doubted. He was seen by Him as a veritable follower and disciple. Every idea to justify this action, character and repeated appeals to Judas were subsumed in the above understanding.

However, Jesus' foreknowledge does not connote the predestination or ordination that Judas will and or must at all cost be His traitor. Another point is that Judas never at all believes in Christ. It is true he fell from the position of an apostle. But in reality, he had no genuine conversion linking him with Jesus. Consequently, he was all through the "“son of perdition who was lost because he was never "saved" (635).

Thus, the highest title he had for Jesus was a Rabbi (Mt. 26:25). He never called Him 'Lord.' He was a typical symbol of warning in Scriptures to those who are not committed followers of Christ who though are in His fold but do not shear in His Spirit (Rm. 8:9). Martin sums up his view with the statement that "he leaves the gospel story 'a doomed and downed man' because he chose it so, and God confirmed him in that dreadful choice" (635).

\section{Judas Misused his Privilege for Salvation}

According to Kepler (535) Judas the only Judaean disciple was a person with promising leadership ability. He had the "common hope of sharing a place of importance in the coming kingdom." He occupied an important position as the treasurer among the twelve (Jn. 12:6; 13:29). Nevertheless, his name is actually placed last on the list of the disciples. This was occasioned by his betrayal of Jesus. In some Eastern Church lists, it is found at the third or sixth. As a result of his conspiracy against Jesus, early Christians used to fast penitently on Wednesdays.

Judas was disgruntled against Jesus because of His acceptance of the anointing. He was a greedy person. He desired thirty pieces of silver as against Jesus (Mt. 26:15; Za 11:12). But he later dumped the money at the Temple and remorsefully hung himself. He did not realize his betrayal of Jesus would lead to His death. After Jesus was condemned to be executed, Judas cried, "I have sinned in betraying innocent blood" (Mt. 27:14). It was then he threw the pieces of silver into the Temple, and hung himself (Kepler, 536). The area designated as the "field of blood" where he committed suicide has been located at the meeting point of the valleys of kidron, Tyropoeon, and Hinnom. Judas "remains one of the enigmatic figures of the NT" (536).

Judas Lured by Materialism, Dishonesty and Greed Judas is also reported to have been a steward to Jesus and the other disciples. But he was covetous and dishonest from the beginning of his membership of the group (Jn. 12:16). The temptation of money led him to betray Jesus. However, Jesus was aware of his planned betrayal. He spoke about it. But the consequences of his guilt caused him to despair and 
killed himself (Funk and Wagnals New Encyclopedia, 282).

Blair describes him as the most enigmatic person in the Gospel story. However, it was with enthusiasm that he responded to Jesus and His proclamation. He was avaricious, dishonest and could not resists temptation toward personal gain (Jn. 12:46; Mt. 26:14-16). He participated in the bread and wine and yet betrayed Jesus (Lk. 22:14-23). His doomed end portrays the consequence of evil. The piece of land where he died was purchased and named the "field of blood" (Blair, 1006-1007).

D. J. Williams (1992:406) also shares the view that ordinarily, the listing of the disciples comes in a hierarchical order. But Judas' place as the last on the list is mostly about his subsequent activities in Jesus' ministry (Mt. 10:4; Mk. 3:19; Lk. 6:16). He plotted with the Jewish leaders to affect the arrest of Jesus. They had a problem on how they could arrest without stirring up a riot. Judas aided them to achieve their purpose (Mt. 26:5; Mk. 14:2; Lk. 22:2).

Private Gardens were not many in Jerusalem. They were very scarce if at all they exist. There were wealthy and well to do individuals on the slope of Mount olives which was outside the city. One of such might have given his own to Jesus to be used for His times of prayers at the place called Gethsemane (Lk. 22:39). This was known to Judas and there he led Jesus' enemies to arrest him at the sum of thirty silver as Matthew 26:5 alone reports. But it was not the whole amount they had agreed to pay him (Williams, 406).

\section{Jesus Loves, Favours and Honours Judas}

In spite of his disservice to Jesus, Judas still occupies a position of special honour with Him even at the Supper. With the U shape structure of the table, the sitting arrangement follows in an order of the chief couch which is at the circle of the $\mathrm{U}$. The guests would take their places on either side of the host. "The place of honour was to the left and therefore, in a sense, behind the host. The second place was to his right, and the guest in that position would have his back to the host, 'lying close to his breast.' This was the position occupied by 'the disciple... whom Jesus loved' (Jn. 13:23)." Going by John's account, the question of the beloved and Jesus' answer involving the action of handling the bread dipped into the wine to Judas (vs. 23-26) confirms him as the one at the other position of honour which was to the left (Williams, 407).

Furthermore, Williams stresses that, the giving of the bread to Judas by Jesus was an expression of love and favour. The position of honour given to him at the supper also serves as a bond of "friendship with Judas despite his knowledge of Judas intentions" (408). Jesus makes his last appeal to Judas when He says to him,
"What you are going to do, do quickly" (Jn. 13:27). What Jesus implies was for him, that is, Judas to urgently make up his mind to respond to His act of friendship or act otherwise as he had intended. But with the influence of Satan, Judas was resolute on his choice to betray Jesus. With the effect that he cut himself out of the light of the world (Jn. 8:12), Judas surrendered himself to the power of darkness. Thus, he left the room at the night (Jn. 13:30). Williams however, stresses that on that night, the paschal (Easter) moon was shining at the full. Therefore, John uses the concept of the night in a symbolic sense (408). Nevertheless, that the moon shines at night does not nullify the nature of the night. The light of the moon does not equate to that of the sun and in turn to daylight. Night remains night and any hidden act can still be done in it as when the moon does not shine.

No one other than Jesus was aware of what was happening. Judas' departure could have been for any reason. So, the other disciples could not fathom a particular reason that could have made it possible for them to connect it to the betrayal. Some of them had the impression he was sent on errand by Jesus to shop for some food for the feast which was to last for seven days. Others thought, he had gone to give something to the poor (Jn. 13:29).

\section{Judas Armed with Military Officers to Arrest Jesus and Exposes Him with a Kiss}

After Judas' exit from the supper, Jesus accompanied with the other disciples, went to Gethsemane at the Mount of Olives. Judas follows after and executes his plan (Mt. 26:36-56; Mk. 14:26-50; Lk. 22:39-52; Jn. 18:1-14). This night has been known in biblical accounts as "the night in which he was betrayed" (1 Cr. 11:23). Jesus' enemies provided Judas with a group of men and armed military officers to harsh his arrest. Judas was their main leader. They had the light of the moon to find their way. But to prevent any mistake and for the purpose of being exact as to the one who must be arrested at all cost, Synoptic Evangelists conclude that Judas gave them a sign, to identify Jesus with a kiss. This was the usual mode of greeting between the disciples and the rabbis (Mt. 26:47-50; Mk. 14:43-45; Lk. 22:47-48). Judas withdraws and fades away subsequently from other actions against Jesus after he reveals Him to His enemies (Williams, 408).

\section{Judas Renders to Jesus the Greatest Act of Unkindness}

Matthew Henry (1339) comparing Mary's attitude with Judas states that, “....after an instance of the greatest kindness done to Christ, follows an instance of the greatest unkindness..." In consideration of Judas' act of betrayal to Jesus, Matthew opines that, "No bonds of duty or gratitude will hold those that have a devil." 
In view of the statement in verse 15 of Matthew 26: “...he went to them and said, what will ye give me? Matthew Henry (1339) asserts that those to whom Judas went did not send for him. They were not the ones that initiated the proposal for the betrayal. It was not in their thinking that someone as close to Jesus would do this against Him. Therefore, it was Judas' sole intention to act treacherously toward Jesus.

They had no meeting point with him in the open nor was there any opportunity available for them in privacy. They were completely at a lost on how to get at Jesus. They were far from reaching or getting access to Him. But what they greatly lacked, Judas provided by bridging the gap in giving to them and volunteered himself for the services. The rulers had the power and interest to kill Jesus, but they could not have their way until $\mathrm{He}$ was delivered to them by His own disciple (Henry, 1339).

\section{Jesus had neither Quarrel nor Offence against Judas} Judas had nothing on which to bear witness against Jesus. But the rulers sought for this (Mt. 26:59). The only reason Judas betrayed Him was to make money by it. It was not because of any wrong or hatred He had done to him. He had no quarrel with him. To this end, it was simply Judas' love for money and nothing else that he became a traitor against Jesus (Mt. 26:15). Thus, Judas was never contented. He had food to eat and clothes to wear. There were neither necessaries nor conveniences he needed. He just wanted more money out of covetousness. Therefore, it was not the lack of money, but the love of it that drove him into it (Henry, 1339-1340).

\section{Judas Valued Jesus not More than a Slave and Harmful Gains}

The chief priests covenanted with him for thirty pieces of silver (Mt. 26:25). On this note, Matthew Henry (1340) stresses that according to Jewish law, "thirty pieces of silver was the price of a slave - a goodly price at which Christ was valued!" Consequently, Judas a disciple of Jesus had neither regard nor value for His personality than the worth of a slave. It further shows the extent to which the priests also disregarded him and sought to demean His reputation. Yet, Judas one in his circle gave Him out for it. They paid it to him. He was given his wages in hand. They encouraged and got him to themselves. This was what he sought and got in Christ: money and carnality of the world, recognition from people and elites whatever it is and whoever they are as well as encouragement from and toward sin and evil.

In his bargain (v. 16), Judas sought for more opportunities to betray Jesus. Thus, he labored at working out evil and mischief. He spent his time, energy and resources on pleasing self and the devil as it pushes him to be true to his own words and intentions which are but wrong and for him to be false to his supposed Master, Jesus Christ (Henry, 1340).

\section{Judas Terribly Disappointed against Jesus}

According to D. A. Carson (117), "Judas treachery was motivated by avarice, jealousy and a profound disappointment that Jesus was not acting like the Messiah he had expected." One does not subscribe to the last opinion. This view is drawn from the circumstance of anointing by Mary that infuriated him against Jesus, because of His approval of the act and commendation of her as against their condemnation and troubling of her combined with his own hypocritical idea that, it could have been sold to cater for the poor. There was no argument about Jesus being the Messiah. Moreover, at no time did Judas seek to understand or ask of Jesus' opinion about His being the Messiah. Therefore, to draw this connection is misleading. However, Carson agrees with the concept of Judas' greed, inordinate desire and jealousy against Jesus and Mary for her commendation by Him. Judas was also angry against Jesus for His rebuke to him.

Notwithstanding, Carson (117) also asserts that Judas' views Jesus as "acting less and less regal and more like a defeatist on his way to death." This belief does not suit Judas' action of betrayal. If so considered, it would have elicited sympathy and not a hate to lead Him to death. The attitude and actions of Judas' towards Jesus clearly shows a serious disconnect, disappointment and thus, a wide gap separating him from Jesus, everything He stands for and represent.

Macdonald (1301) compares Mary's action against Judas' in the following words: "She valued the Saviour highly. Judas valued Him lightly. Consequently, as against Jesus' kindness to Judas, he regards Him with a dreadful bargain that cost His life.

Mounce (239) delves into a possible cause of Judas' treacherous action as not completely clear. However, he assumes it could be as a result of his feeling of Jesus" "failure" "to take command as a militant messiah it was time for Judas to separate himself from the movement and get what he could out of what appeared to be a last opportunity."

Nevertheless, Mounce (239-240) also reasons that Judas' act could be traced to greed (Jn. 12:6). But in consideration of the rate of a "thirty silver coins (the amount assessed for a bull having gored a slave, Exod. 21:32)," he regards it as "a paltry sum for such an act (cf. Zech. 11:12)." These opinions nonetheless, capture the fact that Judas deliberately plotted and hatched his ulterior motives against Jesus. The scriptural references provide a foreknowledge of the happenings, the disregard and wickedness perceived and perpetuated against Jesus by the world of sin and evil represented by Judas. Consequently, irrespective of the motive Judas 
had, his actions stand in dramatic but real and direct contrast to the generous outpouring of the ointment on Jesus by Mary.

\section{Judas Lived without Faith and Died without Grace}

In his assessment of the role Judas plays and Jesus' response as against the honour He bestows on Mary, Ryle (1993:254) asserts that Jesus declares in verse 24 , that, "It would be better for him if he had not been born." To this end, Ryle states that there is only one idea about this statement. It is the fact that,

It teaches plainly that it is better never to live at all than to live without faith and die without grace. To die in this state is to be ruined forevermore: it is a fall from which there is no rising, a loss which is utterly irretrievable. There is no change in hell: the gulf between hell and heaven is one that no one can cross.

This is an apt description of the doom of Judas, an unrepentant sinful human being.

\section{Judas' Disservice Models Hypocritical Christianity and a Proof against Universal Salvation}

Gundry (116) paints Judas' treachery as a negative example of a hypocritical Christian. He helped the chief priests' plot against Jesus to succeed.

Ryle (254) also harps that the damnation of Judas is evident of the fact that the concept of universal salvation cannot be true. Thus, he asserts that, "if it really were true that all would sooner or later reach heaven, and hell sooner or later be emptied of inhabitants, it could never be said that it would have been 'better for him if he had not been born." Thus, Universal salvation has no basis in Christianity. There is nothing in it that points or gives anyone the idea to think that human beings will at last be wholly saved and be in heaven.

Otherwise, the sacrifice of Jesus will be in vain. God could not have revealed and acted through ages and generation coupled with the sufferings of the saints, martyrs, faithfulness and obedience, commitment and endurance as well as the worship of the believers only for salvation and the reward of heaven to now be generalized irrespective of one's life, belief and deeds. God cannot deny Himself in all His deeds and words. He remains true in all things and to Himself forever. Therefore, the perception of universal salvation is a mere assumption, an imagination of the mind of its proponents. It yields no benefit.

\section{Concept of Service in Christianity from Mary and Judas' Activities with Jesus}

The activities of Mary with Jesus show a positive concept of service in Christianity. But Judas' activities depict a negative approach to it. Moreover, both of them contain evidences from different dimension in this regard. There is the personal, interpersonal, physical and spiritual, humanly, godly, material, and the earthly as well as the heavenly perspectives of it all. Their roles present sharp division between the authenticity of being a Christian and of its false representation. Thus, everything about Mary points to that of a positive model and Judas as an example of a dubious and hypocritical subscription to Christianity.

\section{Concept of Mary's Activities with Jesus}

Mary's activities portray a believer's alignment with the teachings and application of the culture, tradition and values of Christianity as well as a wholehearted belief and dedication to Christ in the overall aspect of human affairs (M. M. Oboh and B. I. Oboh, 2018:7-8). Consequently, the concept of service in Christianity as shown and drawn from Mary's activities with Jesus involves the giving of a deep and strong sense of attention and listening to Him. It imbibes a sound and better knowledge of God with the desire and actions intended to honour Him in service in a manner commensurate with its awareness. It goes with a sense of positive contemplation of the Lord and the things of His kingdom. It brings about devotion to Him, doing things and acting beautifully in His eyes. It urges a commitment and loving relationship with the Lord.

Moreover, Mary's approach to Jesus as an example of a positive concept of service in Christianity involves the exhibition of a life of indifference to mundane things, issues and matters. It absorbs the truth of God's kingdom and Jesus Christ as well as recognizes His power; a thankful life style and service as a compliment. This kind of service gives the highest piece of respect to the Lord, faithful and lovely disposition to Him. It shows and gives acts of true kindness, expresses genuine facts of being a good man, woman, boy or girl and a person.

It accords with the service of tendering good works, noble acts, hospitality, giving of attention to those in need and to the needs they might have. It involves the attitude of not only to listen but to talk to those who have burdens to share. It gives others more attention than to focus on self, and to respond to the cares of others. It is a service that prepares and participates in many acts of love, respect, value and wellbeing. It learns that, right actions are more appropriate and necessary; gives thought and worshipful actions; renders costly and timely service and obedience to God.

Christian service in this regards provides relief in suffering. It possesses a discernable ability, seizes the opportunity to do what is right and good, believes in the Lord's instructions and teachings motivated by 
submission and affection for Jesus; emanates from a grateful and a contented heart in Christ; involves extraordinary act of obedience, service as well as commitment.

In addition to the above, Mary's act of Christian service is a mark of appreciation, inestimable value for God's forgiveness and salvation. It is about determination, courage and refusal to be distracted in the face of opposition, persecution and difficulties; an act of the enhancement of one's love and concern for God; submission, trust and total dependence and devotion to Him as well as an act of righteousness and giving of the highest regard to Jesus.

\section{Concept of Judas Activities with Jesus}

Judas' activities are indeed the direct contrast to the role of Mary in the concept of Christian service. It does not represent the worldview, believer and practices of Christianity. It is characterized by the behaviour of a counterfeit Christian. Thus, it is a model of disservice of the highest level of it that must be avoided. It involves acts of unkindness. It is inhuman and evolves from being bounded to the devil. It is treacherous, heinous and wicked; based on the love of money and materialism. Those who manifest such cannot love, but are ruled by hatred. They lack contentment and are covetous. They have worthless assessment of others.

Judas' model of disservice is a devaluation of humanity, disregard and disrepute of others. It seeks worldly gain in the name and person of Christ. Its intention is to attract influence and recognition. It seeks encouragement to sin and evil. It works mischief, pleasing to self and the devil as well as those who are like minded. Besides, it is the yielding of self to Satan's desires, intentions and inclinations and being false to Christ. It is indicative of greed, avarice and jealousy. It shows a person's hypocritical attitude towards Jesus. It refuses to be corrected; portents separation and a gap from the Lord. It is an evil repayment of the kindness of Jesus; a perpetuation of wickedness as against the generous outpouring of love, honour and worship expected of a believer toward the Lord. Nevertheless, it is an outright disservice to Jesus, a hypocritical example of a believer's duty and a facilitation of misdeed against Him.

\section{Implications of Service in Christianity from Mary and Judas' Activities with Jesus}

Implications like the concept are quite diverse, different and opposite of the perspectives of Mary and Judas. Mary stands for a favourable implication but Judas for a detrimental result. As their disposition in personality, faithfulness, activities and service, loyalty and commitment to Jesus are different, so are the effects on themselves and those that follow after them.

\section{Implications of Mary's Activities with Jesus}

Mary's services have far-reaching implications for good in the earthly and heavenly domain. Thus, it calls for a useful, rewarding, hopeful and optimistic remembrance of the one involved. It attracts honour at the point of execution and provides a rich and good memorial. It brings about the Lord's defense on behalf of the individual as well as His commendation for him or her; leads to a timeless, increase or a growing and lasting blessing in the presence of God and respect among men. It bestows God's favour, forgiveness and justification, promotion on earth, blessings and peace of mind as well as a joyful reward in heaven.

\section{Implications of Judas' Activities with Jesus}

Implications from Judas' activities lead to no good. It has no ultimate gain or benefit for the perpetrator. It is a cause of damnation. Its aftermath on Judas' dissatisfaction and the hanging of himself along with its contradiction to what makes for a positive concept and implications as exemplified by Mary's attitude nullifies the idea of a universal salvation which proposes that everyone will sooner or later reach heaven. Consequently, hell will not be empty. Activities such as perpetrated by Judas will cause a person a place in it.

Therefore, it places one in a position that shows it is indeed better for one never to be born or live at all than to live without faith and to die without grace. In view of the foregoing, it leads to death with grave consequences. One is forever ruined by it, if such dies in the state of disservice to God. It is a fall that leads to an irretrievable state and ends in hell where there is no change.

\section{CONCLUSION}

The issue of the concept of Christian service and its implications as it bothers on Mary and Judas' activities with Jesus is typical of the nature of those in the church. It reveals the manner of professing believers divided on the basis of authentic and superficial Christian life. Mary's activities, service, dedication and devotion as well as the honour, value and reverence lavished on Jesus provides a blueprint and a standard for Christian belief and its corresponding practices.

On the other hand, Judas whole approach, unbelief and behaviour, betrayal, lack of regard, disrespect and devaluation, as well as disservice, counterfeit and phony companionship portray a dramatic reality of characteristics of false believers in the fold of Christianity. They push headlong and are difficult to be restrained from achieving their ulterior and heinous intention no matter the purpose and the expected victim. 
Consequently, Mary stands as a right and suitable model, an example of a godly sense of service and commitment in Christianity. That she was classified or identified somewhere as a notorious or simply as a sinner (Lk. 7:37, 39) does not nullify her sense of conversion and transformation in Christ. She serves to greatness, though that was not her intention. She was all about Jesus and much about Him. She was rich and increases toward Him, not in the riches of the world but in spirituality of faith. Her hope and aspiration to serve and worship Him had no limit. Indeed, she was more about Jesus in everything. Thus, her specially prepared, imported, preserved perfume, procured through her hand-work, labour and resources was not too much for her to express her love and devotion by pouring it to anoint Him in appreciation for her salvation and recognition of His Lordship over her life and all else (Lk. 7:47, 48, 50).

Nevertheless, her designation as a sinner, notorious or otherwise does not place her as the only one who has ever sinned. Not even Simon who had invited Jesus to his house neither the disciples in His company which included Judas and those who recorded the gospel were ever free of sin. Only Jesus is sinless. Every human being depends on Him to be saved. This is exactly what Mary did. The same is true of the other disciples except Judas. Therefore, Simon's accusation of her, "if this man were a prophet, he would have known who is touching him and what kind of woman she is. She's a sinner!" (Lk. 7:39, ISV), was necessitated by ignorance particularly of the fact that unknown to him, she had somewhere encountered Jesus leading to her salvation (Lk. 7:37-47).

In addition to his faulty observation of Mary, his ignorance became more glaring, obvious and plain when he disbelieved and questioned the prophethood of Jesus Christ: "If this man were a prophet, he would have known..." (Lk. 7:39, ISV). By implication, to him as at that time, Jesus neither had the power nor foreknowledge as of a prophet. Notwithstanding the fact that his thoughts were not disclosed yet, Jesus knew his wrong feelings against Him as he had on Mary proved Him as and more than that as "The Prophet" being the incarnate of God (Oboh and B. I. Oboh, 21-25). In clarity of this, Jesus proceeds to tell him the story about a money lender and two debtors with questions based on it directed to him. Thus, Jesus opens a conversation with Simon intended to correct his doubtful, undisclosed presuppositions with the following narrative:

Now the Pharisee who had invited Jesus saw this and told himself, "If this man were a prophet, he would have known who is touching him and what kind of woman she is. She is a sinner!" Jesus told him, "Simon, I have something to ask you." Teacher, he replied ask it," Two men were in debt to a moneylender. One owed him 500 denari and the other 50. When they couldn't pay it back, he generously canceled the debts for both of them. Now which of them will love him more?"

Simon answered, "I suppose the one who had the larger debt cancelled." Jesus told him, "You have answered correctly." Then, turning to the woman, he told Simon, "Do you see this woman? I came into your house. You didn't give me any water for my feet, but this woman has washed my feet...

So I'm telling you that her sins, as many as they are, have been forgiven and that's why she has shown such great love. But the one to whom little is forgiven loves little" (Lk. 7:3947, ISV).

Simon's unbelief and wrongful intent against Jesus and Mary amounted to sin and being sinful. So, she was never alone as a sinner and not even at that point when she was not just one but forgiven. By that she gains perfection and became holy. Therefore, sin is a natural phenomenon to every human and none is exempted: "for all have sinned, and fall short of the glory of God" (Rm. 3:23, NHEB). But Jesus provides the means of reinstatement from sin to a just and holy living in the presence of God (Rm. 3:24-26). This was what Judas lacked and failed to avail with the privilege he had to be one of His disciples. Moreover, he traded his life way in his act of disservice to Him.

In contrast, Mary benefits from her faithful, diligent and conscientious service to Jesus. Her reward was immediate and eternal. Amongst others, she was exonerated, prevented from being molested, bothered and troubled, given peace and blessed to be remembered for her good deeds (Lk. 7:37-50; Mt. 26:613; Mk. 14:3-9;; Jn. 12:1-8). But Judas suffered and perished from his hateful, spiteful and harmful acts characteristics of disservice to the Lord. He was condemned, miserable and dissatisfied, shameful as well as ended in pains and sorrow (Mt. 26:14-16, 17-25, 47-50; Mk. 14:10-11, 43-46; Jn. 12:1-6).

However, sin has no gauge, instrument and tool nor weigh to measure or calibrate the intensity, seriousness or its degree as to whether it is much or little. Jesus' response to Simon with the story of the forgiven debtors was intended to douse, take off or resolve Simon's misconception of the nature of $\sin$ in a manner he could understand and appreciates better (Lk. $7: 40-47)$. This is also quite obvious from the incident of the woman that was caught in adultery (Jn. 8:3-11). The story expresses that some scribes and Pharisees: 
Brought a woman who had been caught in adultery. After setting her before them, they told him "Teacher, this woman has been caught in the very act of adultery.

Now in the law, Moses commanded us to stone such women to death. What do you say?"

They said this to test him, so that they might have a charge against him...

When they persisted in questioning him, he straightened up and told them, "Let the person among you who is without sin be the first to throw a stone at her..."

When they heard this, they went away one by one, beginning with the oldest, and he was left alone with the woman standing there.

Then Jesus stood up and asked her, "Dear lady, where are your accusers? Haven't anyone condemned you?"

"No one sir," she replied. Then Jesus said, "I don't condemn you either. God home, and from now on don't sin anymore."

By the trend of the above incident, the men had supposed as they did to trap Jesus, that the sin of adultery committed by the woman was high or much a sin in comparison to some other sins that would warrant a death sentence. Note that the idea of the presupposition was not due to their ignorance of no compartmentalization of sin but because according to the Scriptures, verse 6, "They said this to test him, so that they might have a charge against him." Therefore, they were well aware of the spiritual fact that sin has no graduation. So what was being contested by them before Jesus was not really about the act of adultery but on the grading of sin. It was on this they wanted to fault Him. And of course, Jesus answered pragmatically using them as sources of the answer and solution to saving the woman from her problem of sin and adultery.

Consequently, Jesus did not assert sin as being of much or little, big or small. In view of the above, what He teaches is the uniformity or congruent spiritual nature of it. Thus, technically, Mary was not the worse of a sinner as an individual with "much" sin. In the way it concerns every person being a sinner requiring to believe in Jesus and to begin a new life of a change attitude subsume in His spirit. So it was with her. She did what is paramount and required in every Christian.

On the basis of the above, every human being is regarded a sinner irrespective of the type of sin ever committed mild or serious. For the same reason, there is no division of faith as small or big to be exercised for salvation. Hence, as all have sinned, so are all to believe in Christ for salvation (Rm. 3:23; Jn. 3:16).

To this end, Mary made the most of her time and privilege with Jesus. As a result, Contemporary believers should take caution as to how they live, relate and serve the Lord. They should imitate the principles of Mary's dedication, value and service for optimum reward in this world and hereafter. Her attitudes should be taught and learned, emulated, encouraged and built on. Besides, restrain is needed on the part of all to prevent the detrimental consequences of the disservice, unbelief and destructive tendencies of Judas. People should key into what is good and fruitful for life in the now and hereafter as they grow in relationships with one another and relate to God in everything.

\section{Acknowledgement}

Many thanks to my wife, Rev. Mrs. B. I. Oboh for her industrious and faithful support in caring for our family and other help she rendered to me in making this research possible and in her co-authorship of it. To my son, Master Osemegbe Michael (Jr.) Oboh, whose memory cheered and kept me strong on the work, I say a very big thank you.

Consequently, we wish to express a strong sense of gratitude to my staff Mrs. M. D. Okonofua, Mrs. Mercy Michael and Mr. Samuel Edogiawerie as well as Mrs. Philo Imasuen for their services in one way or the other toward the successful completion of this study.

\section{Biography}

M. M. Oboh was born at Ibhole (Ibore) Uneah, Irrua in Esan Central Local Government Area of Edo State, Nigeria, $31^{\text {st }}$ March, 1967. He was brought up as a Muslim. Hence, the second of his initials stands for Musa, while the other is Michael being the first name. He got converted to Christianity on $7^{\text {th }}$ June, 1986.

He attended Omoaka Primary School, Agbede in Etsako Central Local Government Area of Edo State, but finished at Okotie - Eboh Primary School, Sapele, Ethiope Local Government Area, Delta State, Nigeria with a Primary School Leaving Certificate in 1978. From there he proceeded to Essi College, Warri, still in Delta State where he had his Secondary School Leaving Certificate in 1984.

Thereafter, having received the call into the Gospel Ministry, he was admitted into the Nigerian Baptist Theological Seminary, Ogbomoso, Oyo State, Nigeria in 1992 and graduated with a BA (Bachelor of Arts degree in affiliation to the University of Ibadan, Oyo State, Nigeria) in 1996, and B.Th (Bachelor of Theology in affiliation to Southern Baptist Theological Seminary, Louisville, Kentucky, USA) in 1996; M.Th (Master of Theology with Islamic Studies as major and minor in Systematic Theology also in affiliation to Southern, USA) in 2000; $\mathrm{PhD}$ in Theology and Christian Ethics as minor, NBTS, Ogbomoso, 2008 and $\mathrm{PhD}$ in World Religions from the University of Jos, Plateau State, Nigeria with affiliation to NBTS, Ogbomoso, 2008. 
He was ordained into the full Gospel Ministry $29^{\text {th }}$ September, 2002 and licensed to preach $1^{\text {st }}$ June, 1996. He was a pastor to several churches, led at different ministerial positions, have several awards and honours. Moreover, he lectures at the Baptist College of Theology, Benin City, Edo State, Nigeria since 2000 and served as the Rector of the College from November, 2009-June, 2020. He is a member of several academic societies and holds other positions at different ministerial and administrative responsibilities; promoted to the rank of a Reader/Associate Professor of Theology and Religious Studies October 1, 2018.

Blessing Imalukho Oboh (Nee Ehize) is the daughter of Mr. \& Mrs. Robert E. Ehize of Igueben in Igueben Local Government Area of Edo State. She was born $5^{\text {th }}$ August, 1975. She accepted Christ in 1986. She has teacher's Grade II Certificate from Esigie College, Abudu, Diploma in Theology AAU Ekpoma, B.Th.RE Baptist College of Theology, Benin City, B.A. Religious Studies AAU Ekpoma, M.A. Religious Studies AAU, Ekpoma. She is pursuing her Ph.D in Religious Studies with emphasis on Christian Theology from the same University.

She was a student pastor at Atteh Baptist Church, Atteh and Igarra Baptist Church, Igarra. She also served as children pastor, New Benin Baptist Church, Benin City and Oka Baptist Church on interim basis. She was licensed to preach in 2004, ordained into the full Gospel Ministry in 2016, served as Bible and Mission Study Chairman (WMU) Edo Baptist Conference. She also held various positions and served in various committees at the Church, Association and Conference levels. She has several awards and honours. Among them are Best student in Hebrew language, BCT, Benin City, 2004, Best Teacher of the Year in C.R.K. by the Ministry of Education, Benin City in 2007, courtesy of Professional Certificate in Christian Education, most Creative Teacher BHS, Benin City, 2008.

She has taught in various primary and secondary schools such as Wisdom Group of Schools, Igueben and Baptist High School, Benin City, where she taught for 11 years. She is a lecturer and currently the H.O.D., Religious Studies at the College of Education, Ekiadolor, Benin City. She is happily married to her caring, faithful and darling husband Rev. Dr. M. M. Oboh, immediate past Rector, Baptist College of Theology, Benin City. The marriage is blessed with a son, Osemegbe Michael (Jnr.) Oboh.

\section{REFERENCES}

1. Kruse, C. G. (1993). "Servant, Service." Dictionary of Paul and His Letters. Gerald F. Hawthorne, Ralph P. Martin and Daniel G. Reid eds. Illinois Intervarsity Press, 869-871
2. Wright, N. T. (1988). "Righteousness." New Dictionary of Theology. Sinclair B. Ferguson, David F. Wright and J. I. Packer. Leicester: Intervarsity Press, 590.

3. Piper, O. A. (1963). "Christian." Dictionary of the Bible. James Hastings, Frederick C. Grant, and H. H. Rowley eds. New York: Charles Scribner's Sons, 137-139.

4. Baker, J. P. (1988). "Love." New Dictionary of Theology. Sinclair B. Ferguson, David F. Wright and P. I. Packer eds. Leicester: Intervarsity Press, 398-400.

5. Martin, G. W. (1988). "Faith." New Dictionary of Theology. Sinclair B. Ferguson, David F. Wright and J. I. Packer eds. Leicester: Intervarsity Press, 246-247.

6. Wright, D. F. (1988). "Christianity and other Religions. New Dictionary of Theology. Sinclair B. Ferguson, David F. Wright and J. I. Packer eds. Leicester: Intervarsity Press, 135-137.

7. Oboh, M. M. (2012). "Holiness as a Means of Advancing in God's Power: A Lesson from Saul's Life." EPHA (Ekpoma Journal of Religious Studies), Vol. 9, No. 1 and 2. J. A. Onimhawo et al eds. 319-338.

8. Porter, S. E. (1993). "Holiness, Sanctification." Dictionary of Paul and His Letters. Gerald F. Hawthorne, Ralph P. Martin and Daniel G. Reid eds. Leicester: Intervarsity Press, 397-402.

9. Pellet, D. C. (1962). "Magdala." The Interpreter's Dictionary of the Bible. George Arthur Buttrick. New York: Abingdon Press, 271.

10. Blair, E. P. (1962). "Mary." The Interpreter's Dictionary of the Bible. George AruthurButtricked. New York: Abingdon Press, 288-290.

11. Palmer, E. H. (1986). "Mary." The International Standard Bible Encyclopedia. Gicoffrey W. Bromiley. Grand Rapids: William B. Eerdmans Publishing Company, 268-269.

12. Mounce, Robert, H. (2011). Matthew. Grand Rapids: Bakers Books.

13. Burger, K. (1953). "Mary Magdalene (Mary of Magdalene)." The Schaff-Herzog Encyclopedia of Religious Knowledge. Samuel Macarlty Jackson et al eds. Grand Rapids: Baker Book House, 225.

14. Throckmorton, B. H. (1963). "Mary." Dictionary of the Bible. James Hastings, Frederick C. Grant and H. H. Rowley eds. New York: Charles Scriber's, 628-629.

15. Smalley, S. S. (1982). "Mary." New Bible Dictionary. J. D. Douglas eds. Leicester: Intervarsity Press, 746-748.

16. Macalister, R. A. S. (1963). "Bethany.” Dictionary of the Bible. James Hastings, Frederick C. Grant and H. H. Rowley eds. New York: Charles Scribner's Sons, 98.

17. Birdsall, J. N. (1986). "Bethany." New Bible Dictionary. J. D. Douglas, eds. Leicester: Intervarsity Press, 132. 
18. Clark, K. W. (1962). "Bethany." The Interpreter's Dictionary of the Bible. George Athur Buttrick, eds. New York: Abingdon Press, 382-388.

19. Anderson, G. (2009). "Bethany." The Zondervan Encyclopedia of the Bible, Vol.1A-C, Merrill C. Tenney, eds. Grand Rapids: Zondervan. 562-563.

20. Smith, D., \& W. Forster. (1963). "Judas." Dictionary of the Bible. James Hastings, Frederick C. Grant and H. H. Rowley eds. New York: Charles Scribner's Sons, 535.

21. Martin, R. P. (1982). "Judas Iscariot." New Bible Dictionary. J. D. Douglas et al eds. Leicester: Universities and Colleges Christian Fellowship. 634-635.

22. Kepler, T. S. (1963). "Judas Iscariot." Dictionary of the Bible. James Hastings, Frederick, C. Grant and H. H. Rowing eds. New York: Charles Scribner's Sons, 535-536.

23. Buchanan, G. W. (1982). The International Standard Bible Encyclopedia. Vol. K-J. Geoffrey eds. Grand Rapids: William B. Eerdmans Publishing Company. 1151.

24. Carson, D. A. (1994). "Matthew." The Expositor's Bible Commentary. New Testament. Kenneth L. Barker and John R. Knollenberg III eds. Grand Rapids: Zondervan Publishing House. 1-135.

25. Henry, M. (1972). Commentary on the Whole Bible. Leslie F. Church ed. Grand Rapids: Zondervan Publishing House.

26. Wilson, Neil, S. (1591). "Lazarus' Sister Mary." Life Application Study Bible, NIV. Bruce B. Barton ed. Carol Stream: Tyndale House Publishers, Inc., 1591.

27. Macdonald, W. (1995). Believer's Bible Commentary. Art Forstad ed. Nashville: Thomas Nelson Publishers.

28. Brown, J. K. (2015). Matthew. Mark L. Strauss and John H. Walton eds. Grand Rapids: Baker Books.
29. Ryle, J. C. (1993). Matthew Expository Thoughts on the Gospels. Arthur McGrath and J. I. Packer eds. Wheaton: Crossway Books.

30. Keener, C. S. (1993). The IVP Bible Background Commentary: New Testament. Downer Grove: Intervarsity Press.

31. Gundry, Robert, H. (2010). Commentary on the New Testament: Verse-by-verse Explanations with a Literal Translation. Peabody: Hendrickson Publishers.

32. Williams, D. J. (1992). "Judas Iscariot.” Dictionary of Jesus and the Gospels. Joel B. Green, Scot McKnight and I. Howard Marshall eds. Leicester: Intervarsity Press. 406-408.

33. "Mary Magdalene, Saint." (MCMLXXV). Funk and Wagnalls New Encyclopedia, Vol. 16. Leon L. Bram, William H. Hendelson and Joseph Laffan Morel eds. New York: Funk and Wagnalls, Inc. 58.

34. Oboh, M. M., \& B. I. Oboh. (2018). "Moses Receipt of Jethro and its Biblical Lessons for Christian towards Good Manners." Journal of Philosophy, Culture and Religion. Sukumar Senthilkumar, S. Saravanakumar and Mohammad Q. Shormanieds. New York: IISTE. 7-16.

35. Oboh, M. M., \& B. I. Oboh. (2018). "The Christian God is not a God."Journal of Philosophy, Culture and Religion. Sukumar Senthilkumar, S. Saravanakumar and Mohammad Q. Shormanieds. New York: IISTE. 17-35.

36. Piper, O. A. (1963). "Christianity." Dictionary of the Bible. James Hastings, Frederick C. Grant, and H. H. Rowley eds. New York: Charles Scribner's Sons. 139

37. "The Passion and Resurrection of Jesus (26:628:20)." The Expositors Bible Commentary Abridged edition: New Testament. Kenneth L. Barker and John R. Kohlenberger III eds. Grand Rapids: Zondervan, 117. 